\title{
Association of Vitamin D Receptor Polymorphisms to Pulmonary Tuberculosis in Turkish Patients: An Up-to-date Meta-Analysis and A Case-Control Study
}

\section{Türk Hastalarda Vitamin D Reseptörü Polimorfizmleri ve Pulmoner Tüberküloz Ilișkisi: Güncel Meta Analizi ve Vaka-Kontrol Çalıșması}

\author{
Ceren ACAR'(ID), Harika GÖZÜKARA BAG̃²(iD), Refika Dilara VAizOG̃LU3(IiD)
}

\footnotetext{
${ }^{1}$ Department of Moleculer Biology and Genetics, İnönü University Faculty of Science and Literature, Malatya, Turkey

${ }^{2}$ Department of Biostatistics and Medical Informatics, Inönü University Faculty of Medicine, Malatya, Turkey

${ }^{3}$ Department of Biology, Hacettepe University Faculty of Science, Ankara, Turkey
}

Cite this article as: Acar C, Gözükara Bağ H, Vaizoğlu RD. Association of vitamin D receptor polymorphisms to pulmonary tuberculosis in Turkish patients: An up-to-date meta-analysis and a case-control study. FLORA 2021;26(3):477-87.

\begin{abstract}
Introduction: Tuberculosis is a major global health issue, threatening millions of lives every year. To understand the interactions between host and the pathogenic factors, many association studies are being held in different populations and most of the time results are controversial. Vitamin $D$ receptor is one of the immunomodulatory molecules that may have an effect on susceptibility to tuberculosis. Up to now, there was no positive association reported with the tuberculosis and Fok I or Taq I polymorphisms of VDR gene in tuberculosis patients of Turkish origin. The aim of this study was to make an updated meta-analysis and a case-control study in our group of patients for figuring out the association between Fok I and Taq I polymorphisms of VDR and TB.

Materials and Methods: In the present study, association of pulmonary tuberculosis and VDR gene's Fok I (rs 2228570) and Taq I (rs20731236) polymorphisms were investigated in our patient group from Malatya, and a comparison was made by a meta-analysis with the mentioned polymorphisms. Ninety-four healthy controls and 80 patients are subjects of case control study. The samples are genotyped for Taq I and Fok I polymorphisms by using TaqMan SNP genotyping kits. The allelic and genotypic distributions were analyzed by exact significance of the Pearson's test or Fisher's exact tests. Meta-analyses for each SNP were conducted under four different genetic models. The statistical significance of the pooled ORs was determined by a Z test and publication bias was evaluated by Egger's test.

Results: Our case control study Taq I polymorphism showed no significant association to TB which also matched with our meta-analysis. On the other hand, for Fok I polymorphism, genotypes and allele frequencies were significantly different in our focus group ( $p 0.044)$. Sex based analysis gave significantly different results in women with TB as well even though our meta-analysis showed no association to that polymorphism.

Conclusion: The reasons underlying the susceptibility to TB is still not clear. The immune response process is so complex and many molecules are taking part in these reactions. So, there are a lot of candidate molecules to be checked in the association studies. VDR is still one of those molecules and may be other than by checking single SNPs, haplotypes could be under investigation with bigger populations.
\end{abstract}

Key Words: Tuberculosis; VDR polymorphisms; Genotyping; Vitamin D; Association study 


\title{
ÖZ \\ Türk Hastalarda Vitamin D Reseptörü Polimorfizmleri ve Pulmoner Tüberküloz llișkisi: Güncel Meta Analizi ve Vaka-Kontrol Çalıșması
}

\author{
Ceren ACAR¹, Harika GÖZÜKARA BAĞ², Refika Dilara VAiZOG̃LU³
}

\footnotetext{
1 İnönü Üniversitesi Fen Edebiyat Fakültesi, Moleküler Biyoloji ve Genetik, Malatya, Türkiye

2 İnönü Üniversitesi Tıp Fakültesi, Biyoistatistik ve Tıp Bilișimi Anabilim Dalı, Malatya, Türkiye

3 Hacettepe Üniversitesi Fen Fakültesi, Biyoloji, Ankara, Türkiye
}

Giriş: Tüberküloz küresel bir halk sağlığı problemidir ve her yıl milyonlarca insanın hayatını tehdit etmektedir. Konak ve patojenik faktörler arasındaki etkileşimlerin anlaşılabilmesi için farklı popülasyonlarda birçok bağlantı çalışması yürütülmekte ancak bu çalışmalar çoğu zaman tartışmalı bir şekilde sonuçlanmaktadır. Vitamin D reseptörü (VDR) tüberküloza yatkınlıkta ya da dirençte etkisi olduğu düşünülen immünmodülatör faktörlerden bir tanesidir. Türk popülasyonunda VDR polimorfizmleri ile tüberküloza yatkınlık arasında bağlantı olduğunu rapor eden bir çalışma bulunmamaktadır. Bu nedenle hasta grubumuzda tüberküloz ve VDR geninin Fok I ve Taq I polimorfizmleri arasındaki bağlantıyı incelemek için bir vaka-kontrol çalışması ve meta -analizi yapmayı amaçladık. Sunduğumuz bu çalışma ülkemiz popülasyonunda Fok I polimorfizmi ile tüberküloza yatkınlık arasında istatistiksel olarak anlamlı bağlantı gösteren ilk çalısmadır.

Materyal ve Metod: Sunduğumuz bu çalışmada Malatya ili ve çevresinden oluşturulmuş hasta grubumuzda VDR'nin Fok I (rs2228570) ve Taq I (rs20731236) polimorfizmleri ile pulmoner tüberküloz bağlantısını taranmış ve sözü edilen polimorfizmlere yönelik bir meta analizi ile karşılaştırılmıştır. Bu doğrultuda vaka kontrol çalışmasına 94 sağıkı birey ve 80 hasta dahil edilmiştir. Örnekler TaqMan SNP genotipleme kitleri aracılığı ile Taq I ve Fok I polimorfizmleri için genotiplendirilmiştir. Alelik ve genotipik dağılımlar, Pearson kesin ki-kare ya da Fisher kesin ki-kare testleri ile incelenmiştir. Meta analizleri her polimorfizm için dört ayrı genetik model altında yürütülmüştür. Ortak odds oranlarının anlamlıı̆ı Z testi ile değerlendirilmiştir. Yayın yanlılığının belirlenmesi için Egger testi kullanılmıştır.

Bulgular: Vaka-kontrol çalışmamız Taq I polimorfizmi ile tüberküloz arasında anlamlı bir ilişkiye ulaşamamıştır ve bu bulgu meta analizi çalışması ile örtüşmektedir. Diğer yandan Fok I polimorfizmi genotipleri ve alel frekanslarının hedef hasta grubumuzda istatistiksel olarak anlamlı farklıı̆g sahip olduğu bulunmuştur $(p=0.044)$. Cinsiyete bağlı analizler de benzer şekilde istatistiksel olarak anlamlı bir sonuca ulaşmışken meta analizinde cinsiyetle ilişkili bir bağlantı bulunamamıştır.

Sonuç: Tüberküloza yatkınlı̆ın altında yatan nedenler hala açık değildir. Infeksiyonlara karşı immün yanıt süreci karmaşık bir süreçtir ve bu reaksiyonlarda birçok molekül görev almaktadır. Vitamin D reseptörü bu moleküllerden sadece bir tanesidir ve tüberküloza yatkınlık için bu aday moleküllerin polimorfizmlerinin daha kapsamlı çalışmalarla incelenmesine ihtiyaç duyulmaktadır.

Anahtar Kelimeler: Tüberküloz; VDR polimorfizmleri; Genotipleme; D vitamini; Bağlantı çalışması

\section{INTRODUCTION}

Tuberculosis (TB) is an important cause of morbidity and mortality worldwide. $1 / 3$ of the population is infected with Mycobacterium tuberculosis (MTB). According to World Health Organization 2019 Global Tuberculosis Report, 10 million people were infected with the disease and 1.2 million lives were lost in $2018^{[1]}$. Tuberculosis accounts for $2.5 \%$ of all diseases worldwide and $26 \%$ of preventable deaths ${ }^{[2]}$. It can remain in the latent phase for a very long period of time after infecting the individuals. Although some of the infected individuals show symptoms, the disease never develops in some, even $\sim 90 \%$ of these individual's situations are improved by the immune system's response. As seen in many infectious diseases, the differences between the numbers of infected and sick people are caused by differences in balance between host defense and the virulence of the organism. The mechanisms that prevent the disease phenotype in some infected individuals cannot be understood exactly. The susceptibility to active disease can be related with genetic factors ${ }^{[2]}$.

Evidence from epidemiological studies shows a link between vitamin-D deficiency and tuberculosis. In the UK and Indonesia, levels of serum $25(\mathrm{OH}) \mathrm{D}_{3}$ have been found to be lower in TB patients, which is also related with disease severity. $1.25(\mathrm{OH}) \mathrm{D}_{3}$ which is the active metabolite 
of vitamin $\mathrm{D}$-an immunomodulatory molecule. $1,25(\mathrm{OH}) \mathrm{D}_{3}$ is converted from 25 hydroxyvitamin D3 by $1 \alpha$-hydroxylase enzyme. When $M$. tuberculosis infection activates the receptors' innate immune system, the following signaling events upregulates the expression of $1 \alpha$-hydroxylase and vitamin $\mathrm{D}$ receptor (VDR) in monocytes and macrophages and this leads to increased potential binding of $1,25(\mathrm{OH}) \mathrm{D}_{3}$ to VDR. Antimicrobial peptides like cathelicidins are involved in the first line of defense against infections and LL-37 is one of the members of cathelicidin family which is the only member of this family identified in humans, its production may be enhanced by $1,25(\mathrm{OH}) \mathrm{D}_{3}$. This peptide modulates the immune system by attracting monocytes, $\mathrm{T}$ cells and neutrophils to the infection region. LL-37 production is upregulated in neutrophils and macrophages with the presence of $1,25(\mathrm{OH}) \mathrm{D}_{3}{ }^{[3]}$.

The nuances found on VDR gene could affect the cellular functions of $1,25(\mathrm{OH}) \mathrm{D}_{3}$ and could be link to disease susceptibility. In many populations, several association studies have been held related with VDR polymorphisms and susceptibility to TB but the results are inconsistent.

We aimed to investigate the association of Fok I (rs2228570) and Taq I (rs20731236) polymorphisms of VDR gene and susceptibility to pulmonary tuberculosis (PTB) in a meta-analysis and also in a case-control study with a group of Turkish patients.

\section{MATERIALS and METHODS}

\section{Subjects}

Turkish pulmonary tuberculosis patients and age and sex-matched healthy control individuals were the subjects of this study. Patients were recruited from the Malatya Provincial Health Directorate and molecular study was performed in Department of Moleculer Biology and Genetics. The study was performed in accordance with the guidelines of the Declaration of Helsinki and was approved by local ethics committee (Protocol \#2016/150). All subjects were informed about the procedures, and consent was taken before the start of the study. Ninety-four control subjects and 80 patient subjects were included in the analysis for Fok I (rs2228570) genotyping and
93 control subjects and 78 patient subjects were included in the analysis for Taq I (rs20731236) genotyping depending on the reaction quality.

\section{Genotyping}

Genomic DNA was extracted from peripheral blood using a commercial kit (PureLink ${ }^{\circledR}$ Genomic DNA Mini Kit; Invitrogen, Carlsbad, CA, USA), according to the manufacturers' protocol. All samples were coded to ensure anonymity. The quantity of DNA was measured by Qubit assays (Thermo Fisher Scientific Inc., USA). DNA samples were stored at $-20^{\circ} \mathrm{C}$ until analysis. All samples were genotyped using the TaqMan ${ }^{\circledR}$ Single-nucleotide polymorphism (SNP) Assays (Applied Biosystems, Foster City, CA, USA): C_12060045_20 for rs2228570 and C_2404008_10 for rs20731236. All assays were performed in total volume of $10 \mu \mathrm{L}$, using TaqMan Genotyping MasterMix on 96-well plates. Negative control and three samples with known genotypes were included in each assay. StepOnePlus ${ }^{\mathrm{TM}}$ Real-Time PCR System (Applied Biosystems, Foster City, CA, USA) was used for genotyping reactions.

\section{Statistical Analysis for Case-Control Study}

The data was summarized by count and percent. Hardy-Weinberg equilibrium was tested by a chi-square distribution with 1 degrees of freedom. Differences between the groups due to allelic and genotypic distributions were analyzed by exact significance of the Pearson's test or Fisher's exact tests where appropriate. In comparisons, the significance level was considered as 0.05.

\section{Meta-Analysis}

To evaluate the association between PTB and VDR polymorphisms, odds ratio (OR) was used as the effect size. To decide the appropriate meta-analytic method, heterogeneity among studies were interpreted by I2 and Cochran's Q test statistics. The studies considered as heterogeneous if $\mathrm{I} 2>50 \%$ or $\mathrm{p}<0.05$ for $\mathrm{Q}$ statistic ${ }^{[4]}$. Since for all genetic models the heterogeneity was high, the DerSimonian-Laird (DSL) random effects model was used to achieve the pooled effect size. Meta-analyses were conducted under four different genetic models for each SNP. For Taq 1: T allele vs $\mathrm{t}$ allele, TT genotype vs t-allele carriers 
( $\mathrm{Tt}+\mathrm{tt})$, T-allele carriers (TT+Tt) vs $\mathrm{tt}$ genotype and TT genotype vs tt genotype. For Fok 1; F allele vs $\mathrm{f}$ allele, FF genotype vs f-allele carriers $(\mathrm{Ff}+\mathrm{ff})$, F-allele carriers $(\mathrm{FF}+\mathrm{Ff})$ vs ff genotype and FF genotype vs ff genotype. The statistical significance of the pooled ORs was determined by $\mathrm{a} z$ test and publication bias was evaluated by Egger's test. In all analyses, the significance level was considered as 0.05 and statistical analyses were done by STATA 14.0 software (Stata Corporation, College Station, Texas, USA).

\section{Literature Search}

Search words VDR or vitamin D receptor and PTB were used on databases (PubMed, Web of Science, Google Scholar) date up to November 2019. To find other appropriate studies, we also examined the references of the key studies. The selection process of the studies included in the meta-analysis is given by the flow diagram in Figure 1.

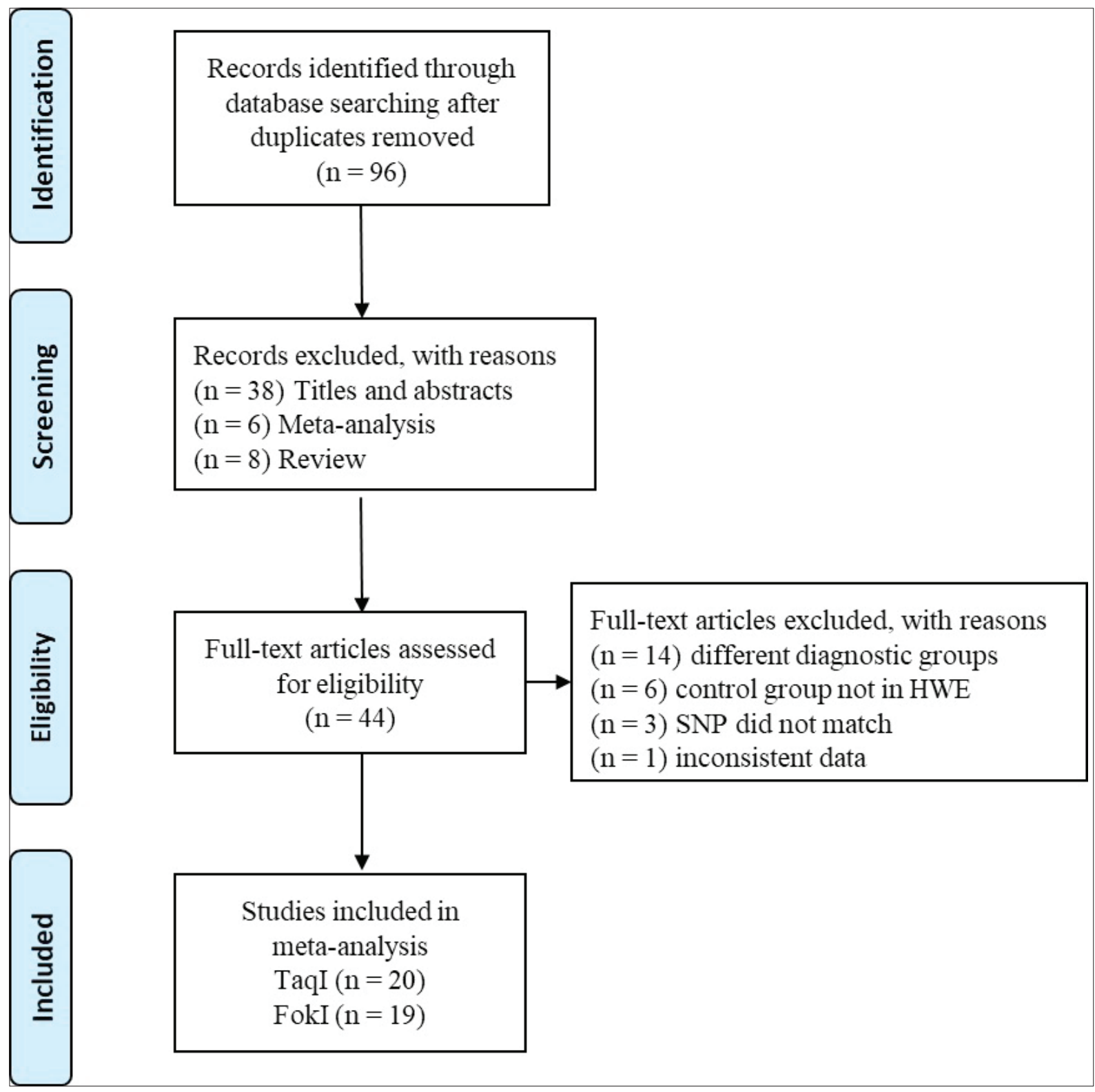

Figure 1. Flow diagram of the selection process of the studies included in meta-analysis. 


\section{Inclusion-Exclusion Criteria}

Our hypothesis was to investigate the effect of VDR Fok I and Taq I polymorphisms on susceptibility to PTB. To test that hypothesis, our meta-analysis must have met the following criteria: i) the studies which concern the association between VDR SNPs and PTB and also healthy individuals as controls in case-control studies were included in meta-analysis; ii) the studies do not have a genotype distribution of control population in Hardy-Weinberg Equilibrium (HWE); iii) and in which patients diagnosed with different type of TB rather than PTB; iv) the subjects with multiple diseases; v) the publications not in English were excluded. The characteristics of the studies included in meta-analysis resulted from the selection process are given in Table 1 for Taq I and in Table 2 for Fok I polymorphisms.

\section{RESULTS}

In the case-control study, we could not find a significant association for Taq I genotype and allele frequencies (In controls: TT-49.5\%, Tt-39.8 $\%$, tt-10.7 \%, in patients: TT-52.6\%, Tt-29.5\%, $\mathrm{tt}-17.9 \%$ for the allele frequencies $\mathrm{T}$ 69.4\% and $\mathrm{t} 30.6 \%$ in controls and $\mathrm{T}$ 67.3\% and $32,7 \%$ in patients). The sex-based analysis was also performed, and the results were again not significantly different. The results of the case control study of Taq I is given in Table 3 and the sex related analysis of Taq I is given in Table 4. On the contrary, for Fok I polymorphisms the genotypes and allele frequencies were significantly different in our focus group (In controls: FF63,8\%, Ff-28.7\%, ff-7.5\% in patients: FF-45\%, Ff-45\%, ff-10\% p 0.044 and allele frequencies in controls $\mathrm{F}-78,2 \%, \mathrm{f}-21,8 \%$ and in patients

Table 1. Characteristics of the studies included in meta-analysis for Taq I

\begin{tabular}{|c|c|c|c|c|c|c|c|}
\hline \multicolumn{8}{|c|}{ Genotype Distribution } \\
\hline \multirow[b]{2}{*}{ First author, year } & \multicolumn{3}{|c|}{ Case } & \multicolumn{3}{|c|}{ Control } & \multirow[b]{2}{*}{ Ethnicity } \\
\hline & TT & $\mathrm{Tt}$ & $\mathrm{tt}$ & $\pi \mathrm{T}$ & $\mathrm{Tt}$ & tt & \\
\hline Bellamy, 1999 & 204 & 177 & 27 & 188 & 177 & 49 & African \\
\hline Wilkinson, 2000 & 21 & 16 & 2 & 45 & 58 & 13 & Asian in West London \\
\hline Delgado, 2002 & 325 & 30 & 3 & 96 & 10 & 0 & Cambodian \\
\hline Bornman, 2004 & 174 & 132 & 37 & 331 & 253 & 50 & West African \\
\hline Lombard, 2006 & 50 & 29 & 5 & 47 & 34 & 1 & Venda of South Africa \\
\hline Olesen, 2007 & 150 & 145 & 25 & 161 & 150 & 34 & West African \\
\hline Banoei, 2010 & 8 & 33 & 19 & 33 & 24 & 5 & Iranian \\
\hline Ates, 2011 & 49 & 65 & 14 & 30 & 39 & 11 & Turkish \\
\hline Kang, 2011 & 134 & 14 & 1 & 85 & 8 & 1 & Korean \\
\hline Alexandra, 2013 & 16 & 52 & 0 & 43 & 48 & 19 & Romanian \\
\hline Rashedi, 2014 & 35 & 34 & 15 & 38 & 41 & 11 & Iranian \\
\hline Salimi, 2014 & 52 & 54 & 14 & 67 & 50 & 14 & Iranian \\
\hline Mestre, 2015 & 51 & 33 & 2 & 58 & 38 & 1 & Venezuelan \\
\hline Harishankar, 2016 & 36 & 39 & 15 & 42 & 39 & 8 & Indian \\
\hline Jafari, 2016 & 38 & 46 & 12 & 56 & 58 & 8 & Iranian \\
\hline Lee, 2016 & 186 & 12 & 0 & 149 & 20 & 1 & Han Taiwanese \\
\hline Panwar, 2016 & 66 & 28 & 12 & 90 & 14 & 2 & Indian \\
\hline Rizvi, 2016 & 92 & 27 & 11 & 104 & 22 & 4 & Indian \\
\hline Devi, 2018 & 86 & 73 & 10 & 116 & 86 & 25 & Indian \\
\hline Silva-Ramírez, 2019 & 132 & 110 & 15 & 228 & 199 & 30 & Mexican \\
\hline This study, 2019 & 41 & 23 & 14 & 46 & 37 & 10 & Turkish \\
\hline
\end{tabular}


Table 2. Characteristics of the studies included in meta-analysis for Fok I

\begin{tabular}{|c|c|c|c|c|c|c|c|}
\hline \multicolumn{8}{|c|}{ Genotype Distribution } \\
\hline \multirow[b]{2}{*}{ First author, year } & \multicolumn{3}{|c|}{ Case } & \multicolumn{3}{|c|}{ Control } & \multirow[b]{2}{*}{ Ethnicity } \\
\hline & $\mathrm{FF}$ & $\mathrm{Ff}$ & $\mathrm{ff}$ & $\mathrm{FF}$ & $\mathrm{Ff}$ & $\mathrm{ff}$ & \\
\hline Wilkinson, 2000 & 24 & 14 & 1 & 74 & 39 & 2 & Asian in West London \\
\hline Bornman, 2004 & 258 & 138 & 20 & 444 & 242 & 32 & West African \\
\hline Liu, 2004 & 29 & 63 & 28 & 85 & 120 & 35 & Han Chinese \\
\hline Lombard, 2006 & 43 & 21 & 2 & 66 & 18 & 2 & Venda of South Africa \\
\hline Olesen, 2007 & 198 & 106 & 16 & 207 & 118 & 19 & West African \\
\hline Banoei, 2010 & 30 & 21 & 9 & 29 & 27 & 6 & Iranian \\
\hline Marashian, 2010 & 97 & 57 & 10 & 15 & 30 & 5 & Iranian \\
\hline Ates, 2011 & 58 & 60 & 10 & 35 & 37 & 8 & Turkish \\
\hline Kang, 2011 & 30 & 58 & 15 & 41 & 43 & 21 & Korean \\
\hline Singh, 2011 & 55 & 40 & 6 & 96 & 110 & 19 & Indian \\
\hline Wu, 2013 & 72 & 96 & 45 & 101 & 88 & 22 & Chinese Kazakh \\
\hline Rashedi, 2014 & 44 & 33 & 7 & 50 & 32 & 8 & Iranian \\
\hline Salimi, 2014 & 65 & 44 & 11 & 93 & 31 & 7 & Iranian \\
\hline Sinaga, 2014 & 27 & 42 & 7 & 30 & 34 & 12 & Indonesian \\
\hline Mestre, 2015 & 34 & 47 & 12 & 26 & 60 & 16 & Venezuelan \\
\hline Wu, 2015 & 57 & 70 & 24 & 226 & 181 & 46 & Chinese \\
\hline Lee, 2016 & 44 & 104 & 50 & 51 & 87 & 32 & Han Taiwanese \\
\hline Devi, 2018 & 59 & 106 & 4 & 119 & 90 & 18 & Indian \\
\hline Silva-Ramírez, 2019 & 76 & 119 & 62 & 80 & 218 & 159 & Mexican \\
\hline This study, 2019 & 36 & 36 & 8 & 60 & 27 & 7 & Turkish \\
\hline
\end{tabular}

Table 3. Genotype and allele frequencies for Taq I

\begin{tabular}{lcccccccc}
\multicolumn{4}{c}{ Genotype $\mathbf{n}(\%)$} \\
\hline Group & TT & Tt & tt & p & Hardy-Weinberg & T & t & p \\
\hline Control & $46(49.5)$ & $37(39.8)$ & $10(10.7)$ & & 0.537 & $129(69.4)$ & $57(30.6)$ & 0.685 \\
Patient & $41(52.6)$ & $23(29.5)$ & $14(17.9)$ & & 0.003 & $105(67.3)$ & $51(32.7)$ &
\end{tabular}

Table 4. Sex related analysis for Taq I

\begin{tabular}{|c|c|c|c|c|c|c|c|}
\hline \multicolumn{4}{|c|}{ Genotype n(\%) } & \multicolumn{3}{|c|}{ Allele n(\%) } & \multirow[b]{2}{*}{$p$} \\
\hline Women & $\mathrm{TT}$ & $\mathrm{Tt}$ & tt & p & $\mathrm{T}$ & $\mathbf{t}$ & \\
\hline Control & $5(31.3)$ & $8(50.0)$ & $3(18.7)$ & \multirow{2}{*}{0.262} & $18(56.3)$ & $14(43.7)$ & \multirow{2}{*}{0.602} \\
\hline Patient & $20(50.0)$ & $11(27.5)$ & $9(22.5)$ & & $51(63.7)$ & $29(36.3)$ & \\
\hline Men & TT & Tt & tt & p & $\mathbf{T}$ & $\mathbf{t}$ & $p$ \\
\hline Control & $41(53.2)$ & $29(37.7)$ & $7(9.1)$ & \multirow{2}{*}{0.709} & $111(72.1)$ & $43(27.9)$ & \multirow{2}{*}{0.995} \\
\hline Patient & $21(55.3)$ & $12(31.6)$ & $5(13.1)$ & & $54(71.1)$ & $22(28.9)$ & \\
\hline
\end{tabular}


Table 5. Genotype and allele frequencies for Fok I

\begin{tabular}{lcccccccc}
\multicolumn{4}{c}{ Genotype $\mathbf{n}(\%)$} \\
\hline Group & FF & Ff & ff & p & Hardy-Weinberg & F & f & p \\
\hline Control & $60(63.8)$ & $27(28.7)$ & $7(7.5)$ & & 0.126 & $147(78.2)$ & $41(21.8)$ & 0.025 \\
Patient & $36(45.0)$ & $36(45.0)$ & $8(10.0)$ & & 0.818 & $108(67.5)$ & $52(32.5)$ &
\end{tabular}

Table 6. Sex related analysis for Fok I

\begin{tabular}{|c|c|c|c|c|c|c|c|}
\hline \multicolumn{4}{|c|}{ Genotype n(\%) } & \multicolumn{3}{|c|}{ Allele $\mathrm{n}(\%)$} & \multirow[b]{2}{*}{$p$} \\
\hline Women & $\mathrm{FF}$ & Ff & $\mathrm{ff}$ & p & $F$ & $f$ & \\
\hline Control & $11(64.7)$ & $3(17.6)$ & $3(17.6)$ & \multirow{2}{*}{0.043} & $25(73.5)$ & $9(26.5)$ & \multirow{2}{*}{0.358} \\
\hline Patient & $14(35.0)$ & $22(55.0)$ & $4(10.0)$ & & $50(62.5)$ & $30(37.5)$ & \\
\hline Men & FF & Ff & ff & & $F$ & $f$ & $\mathbf{p}$ \\
\hline Control & $49(63.6)$ & $24(31.2)$ & $4(5.2)$ & \multirow{2}{*}{0.514} & $122(79.2)$ & $32(20.8)$ & \multirow{2}{*}{0.320} \\
\hline Patient & $22(55.0)$ & $14(35.0)$ & $4(10.0)$ & & $58(72.5)$ & $22(27.5)$ & \\
\hline
\end{tabular}

Table 7. The results of the meta-analyses under different genetic models for Taq I

\begin{tabular}{|c|c|c|c|c|c|}
\hline \multirow[b]{2}{*}{ Genetic model } & \multirow[b]{2}{*}{ OR (95\% C.I.) } & \multirow[b]{2}{*}{$\mathrm{I}^{2}(\%)$} & \multicolumn{3}{|c|}{$\mathbf{p}$} \\
\hline & & & $\mathrm{P}_{\mathrm{Q}}$ & $P_{Z}$ & $P_{E}$ \\
\hline$T$ vs t ${ }^{[21]}$ & $1.123(0.960-1.313)$ & 69.8 & $<0.001$ & 0.147 & 0.155 \\
\hline TT vs $(T t+t t)^{[21]}$ & $1.135(0.950-1.355$ & 60.8 & $<0.001$ & 0.163 & 0.123 \\
\hline$(T T+T t) v s t^{[21]}$ & $1.219(0.869-1.709)$ & 59.0 & $<0.001$ & 0.252 & 0.402 \\
\hline $\mathrm{TT}$ vs $\mathrm{tt}^{[21]}$ & $1.304(0.892-1.905)$ & 64.5 & $<0.001$ & 0.170 & 0.294 \\
\hline
\end{tabular}

Table 8. The results of the meta-analyses under different genetic models for Fok 1

\begin{tabular}{|c|c|c|c|c|c|}
\hline \multirow[b]{2}{*}{ Genetic model } & \multirow[b]{2}{*}{ OR (95\% C.I.) } & \multirow[b]{2}{*}{$I^{2}(\%)$} & \multicolumn{3}{|c|}{$\mathbf{p}$} \\
\hline & & & $P_{Q}$ & $\mathbf{P}_{\mathrm{Z}}$ & $P_{E}$ \\
\hline F vs $f^{[20]}$ & $1.090(0.926-1.283)$ & 76.4 & $<0.001$ & 0.300 & 0.624 \\
\hline FF vs $(F f+f f)^{[20]}$ & $1.142(0.914-1.426)$ & 76.7 & $<0.001$ & 0.243 & 0.771 \\
\hline$(F F+F f)$ vs $\mathrm{ff}^{[20]}$ & $1.030(0.800-1.326)$ & 52.3 & 0.003 & 0.818 & 0.939 \\
\hline FF vs ff $[20]$ & $1.070(0.768-1.491)$ & 67.6 & $<0.001$ & 0.691 & 0.980 \\
\hline
\end{tabular}

F-67.5\% and $\mathrm{f}-32.5 \% \mathrm{p}$ 0.025) and also sex based analysis gave significantly different results in women with TB. The results of genotyping of Fok I polymorphism and sex related analysis was given in Table 5 and Table 6 respectively.
Literature search resulted in 20 studies for Taq I (rs20731237) and 19 studies for Fok I (rs2228570) that met the inclusion criteria. We also included case-control results of this study in the meta-analysis. In tables 7 and 8 , pooled OR 


\begin{tabular}{|c|c|c|c|c|c|}
\hline $\begin{array}{l}\text { Author, } \\
\text { year }\end{array}$ & OR (95\% Cl) & $\begin{array}{l}\% \\
\text { Weight }\end{array}$ & $\begin{array}{l}\text { Author, } \\
\text { year }\end{array}$ & OR (95\% Cl) & $\begin{array}{l}\% \\
\text { Weight }\end{array}$ \\
\hline Bellamy,1999 & $0.79(0.64,0.98)$ & 6.77 & Bellamy,1999 & $0.83(0.63,1.09)$ & 7.32 \\
\hline Wilkinson,2000 & $0.61(0.34,1.08)$ & 3.78 & Wilkinson,2000 & $0.54(0.26,1.13)$ & 3.53 \\
\hline Delgado,2002 & $1.07(0.52,2.19)$ & 2.94 & Delgado,2002 & $0.97(0.46,2.05)$ & 3.47 \\
\hline Bornman,2004 & $1.11(0.91,1.36)$ & 6.81 & Bornman,2004 & $1.06(0.82,1.38)$ & 7.42 \\
\hline Lombard,2006 & $1.07(0.64,1.80)$ & 4.20 & Lombard,2006 & $0.91(0.49,1.69)$ & 4.27 \\
\hline Olesen,2007 & $0.95(0.75,1.20)$ & 6.59 & Olesen.2007 & $0.99(0.73,1.35)$ & 7.03 \\
\hline Banoei, 2010 & $\rightarrow 3.84(2.24,6.56)$ & 4.04 & Banoei, 2010 & $7.40(3.02,18.12)$ & 2.72 \\
\hline Ates, 2011 & $0.93(0.62,1.39)$ & 5.06 & Ates,2011 & $0.97(0.54,1.72)$ & 4.58 \\
\hline Kang,2011 & $1.01(0.45,2.27)$ & 2.51 & Kang,2011 & $1.06(0.44,2.52)$ & 2.83 \\
\hline Alexandra,2013 & $0.96(0.62,1.50)$ & 4.80 & Alexandra,2013 & $2.09(1.06,4.11)$ & 3.86 \\
\hline Rashedi,2014 & $1.14(0.74,1.77)$ & 4.82 & Rashedi,2014 & $1.02(0.56,1.87)$ & 4.38 \\
\hline Salimi,2014 & $1.22(0.84,1.78)$ & 5.33 & Salimi, 2014 & $1.37(0.83,2.25)$ & 5.22 \\
\hline Mestre,2015 & $1.06(0.64,1.75)$ & 4.29 & Mestre,2015 & $1.02(0.56,1.84)$ & 4.47 \\
\hline Harishankar,2016 & $1.39(0.90,2.15)$ & 4.81 & Harishankar,2016 & $1.34(0.74,2.42)$ & 4.46 \\
\hline Jafari,2016 & $1.32(0.88,1.97)$ & 5.12 & Jafari,2016 & $1.30(0.75,2.23)$ & 4.85 \\
\hline Lee,2016 & $0.45(0.22,0.93)$ & 2.93 & Lee, 2016 & $0.46(0.22,0.96)$ & 3.48 \\
\hline Panwar, 2016 & $3.50(1.97,6.23)$ & 3.77 & Panwar,2016 & $3.41(1.76,6.60)$ & 3.97 \\
\hline Rizvi,2016 & $1.78(1.09,2.91)$ & 4.38 & Rizvi,2016 & $1.65(0.93,2.93)$ & 4.61 \\
\hline Devi,2018 & $0.89(0.65,1.21)$ & 5.90 & Devi,2018 & $1.01(0.68,1.50)$ & 6.13 \\
\hline Silva-Ramirez,2019 & $0.95(0.74,1.21)$ & 6.51 & Silva-Ramirez,2019 & $0.94(0.69,1.28)$ & 7.02 \\
\hline This study, 2019 & $1.10(0.70,1.74)$ & 4.65 & This study, 2019 & $0.88(0.48,1.61)$ & 4.39 \\
\hline Overall (1-squared $=69.8 \%, p=0.000$ ) & $1.12(0.96,1.31)$ & 100.00 & Overall (l-squared $=60.8 \%, p=0.000)$ & $1.13(0.95,1.36)$ & 100.00 \\
\hline NOTE: Weights are from random effects analys & & & NOTE: Weights are from random effects analysis & & \\
\hline .152 & 6.56 & & 0552 & 18.1 & \\
\hline a) Forest plot under the T vs t mode & & & b) Forest plot under the $T T$ vs $T t+t$ & & \\
\hline $\begin{array}{l}\text { Author, } \\
\text { year }\end{array}$ & OR $(95 \% \mathrm{Cl})$ & $\begin{array}{l}\% \\
\text { Weight }\end{array}$ & $\begin{array}{l}\text { Author, } \\
\text { year }\end{array}$ & $\mathrm{OR}(95 \% \mathrm{Cl})$ & $\begin{array}{l}\% \\
\text { Weight }\end{array}$ \\
\hline Bellamy, 1999 & $0.53(0.32,0.86)$ & 8.33 & Bellamy, 1999 & $0.51(0.30,0.85)$ & 7.90 \\
\hline Wilkinson,2000 & $0.43(0.09,1.99)$ & 3.28 & Wilkinson, 2000 & $0.33(0.07,1.59)$ & 3.56 \\
\hline Delgado,2002 & $2.10(0.11,40.92)$ & 1.15 & Delgado,2002 & $2.08(0.11,40.53)$ & 1.38 \\
\hline Bornman,2004 & $1.41(0.90,2.21)$ & 8.59 & Bornman,2004 & $1.41(0.89,2.24)$ & 8.11 \\
\hline Lombard,2006 & $5.13(0.59,44.87)$ & 1.96 & Lombard,2006 & $4.70(0.53,41.73)$ & 2.27 \\
\hline Olesen,2007 & $0.78(0.45,1.33)$ & 8.03 & Olesen,2007 & $0.79(0.45,1.38)$ & 7.67 \\
\hline Banoei, 2010 & $5.28(1.82,15.31)$ & 5.05 & Banoei, 2010 & $15.68(4.48,54.81)$ & 4.60 \\
\hline Ates, 2011 & $0.77(0.33,1.79)$ & 6.20 & Ates, 2011 & $0.78(0.31,1.94)$ & 6.02 \\
\hline Kang,2011 & $0.63(0.04,10.17)$ & 1.29 & Kang,2011 & $0.63(0.04,10.28)$ & 1.54 \\
\hline$\longrightarrow$ & $0.03(0.00,0.58)$ & 1.25 & Alexandra, 2013 & $0.07(0.00,1.18)$ & 1.47 \\
\hline Rashedi,2014 & $1.56(0.67,3.63)$ & 6.21 & Rashedi,2014 & $1.48(0.60,3.65)$ & 6.05 \\
\hline Salimi, 2014 & $1.10(0.50,2.42)$ & 6.54 & Salimi, 2014 & $1.29(0.56,2.94)$ & 6.42 \\
\hline Mestre,2015 & $2.29(0.20,25.66)$ & 1.64 & Mestre,2015 & $2.27(0.20,25.83)$ & 1.93 \\
\hline Harishankar,2016 & $2.03(0.81,5.05)$ & 5.81 & Harishankar,2016 & $2.19(0.83,5.75)$ & 5.77 \\
\hline Jafari,2016 & $2.04(0.80,5.20)$ & 5.68 & Jafari, 2016 & $2.21(0.83,5.92)$ & 5.69 \\
\hline Lee, 2016 & $0.28(0.01,7.03)$ & 1.00 & Lee,2016 & $0.27(0.01,6.61)$ & 1.21 \\
\hline Panwar, 2016 & $6.64(1.45,30.43)$ & 3.31 & Panwar, 2016 & $8.18(1.77,37.80)$ & 3.69 \\
\hline Rizvi,2016 & $2.91(0.90,9.40)$ & 4.56 & Rizvi,2016 & $3.11(0.96,10.10)$ & 4.88 \\
\hline Devi,2018 & $0.51(0.24,1.09)$ & 6.68 & Devi,2018 & $0.54(0.25,1.18)$ & 6.61 \\
\hline Silva-Ramirez,2019 & $0.88(0.47,1.67)$ & 7.42 & Silva-Ramirez,2019 & $0.86(0.45,1.66)$ & 7.23 \\
\hline This study, 2019 & $1.82(0.76,4.35)$ & 6.03 & This study, 2019 & $1.57(0.63,3.92)$ & 6.00 \\
\hline Overall (1-squared $=59.0 \%, p=0.000$ ) & $1.22(0.87,1.71)$ & 100.00 & Overall (1-squared $=64.5 \%, p=0.000$ ) & $1.30(0.89,1.90)$ & 100.00 \\
\hline \multicolumn{3}{|l|}{ NOTE: Weights are from random effects analysis } & \multicolumn{3}{|l|}{ NOTE: Weights are from random effects analysis } \\
\hline c) Forest plot under the TT+Tt vs tt & $\begin{array}{l}492 \\
1\end{array}$ & & $\begin{array}{c}.00386 \\
\text { d) Forest plot under the TT vs tt m }\end{array}$ & 259 & \\
\hline
\end{tabular}

Figure 2. Forest graphs under different genetic models for the association between Taq I and PTB.

estimates and 95\% confidence intervals (95\% C.I.) under different genetic models and $\mathrm{p}$ values; for the $\mathrm{Q}$ heterogeneity test $(\mathrm{PQ})$, for the significance of the pooled estimate (PZ) and for the Egger's bias test $(\mathrm{PE})$ are given respectively for Taq I and Fok I polymorphisms. The number of studies included in the meta-analysis under each genetic model is indicated in parentheses by superscripts in the tables. OR estimates, 95\% C.I. and the weights of independent studies are presented by forest plots (Figure 2, Figure 3). No publication bias was determined by the Egger's test. We could not find any association between Taq I or Fok I polymorphism and tuberculosis under any genetic model that were analyzed in meta-analysis and are given in Tables 7 and 8 .

\section{DISCUSSION}

In many studies performed in different populations of the world in different centers, there were inconsistent results related with the VDR polymorphisms and TB susceptibility. The present study aimed to analyze this relation in a meta-analysis and a case control study from our population. We checked the Taq I and Fok I polymorphisms in our population and tried to compare the results with other reports from other regions of the world. In the meta analysis, we 


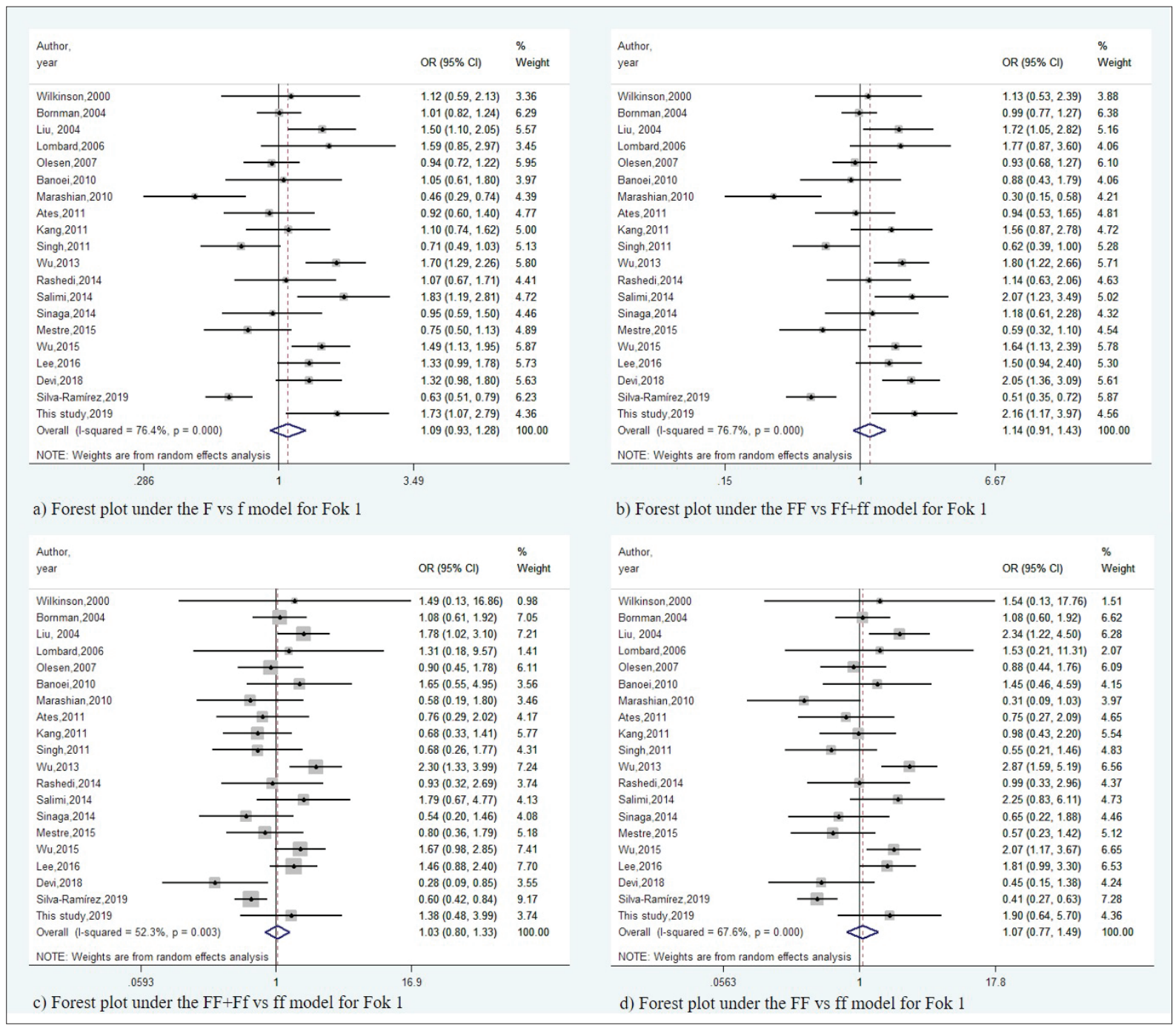

Figure 3. Forest graphs under different genetic models for the association between Fok I and PTB.

could not detect any association between the Fok I and Taq I polymorphisms of VDR gene and pulmonary tuberculosis. Although our case-control study revealed a significant association to Fok I ( $r$ 2228570) polymorphism but on the other side we could not reach a meaningful result with Taq I polymorphisms. According to our results $\mathrm{F}$ allele carriers are protected ( $\mathrm{p}$ 0.025), and also having an FF genotype is a protective characteristic but Ff genotype is susceptible to tuberculosis for Fok I polymorphism (p 0.044). When the analysis run for the sex, we got the significant results for the genotypes as well ( $p$ 0.043) just like in all populations the FF genotypes are protective against TB. These results do not match those of the study of Ates et al., in which the percentages of the genotypes of controls and normal subjects were so close to each other which was another study from Turkish population collected from Istanbul region[5]. The study we present here is the only report that was performed with Turkish PTB patients, which resulted in positive association to Fok I polymorphism.

In the meta-analysis for Taq I, it turned out that having $t$ allele $e^{[6,7]}$ and having $\mathrm{T}^{[8-10]}$ in some populations is a susceptibility factor for tuberculosis, and on the other side, other studies, including our analysis as well, could not find a 
significant association ${ }^{[5,11-24]}$. For other genetic models, the results can be seen in Figure 2.

In several studies, researchers have reported an association to increased risk of TB with Fok I genotypes. On the other side, in many populations, they have found no association between VDR variants and TB patients. For Fok I polymorphism, the protective allele seems to be $f$ in different populations ${ }^{[24,25]}$ and $F$ is protective

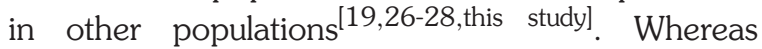
the other populations gave negative association results $[5,7,8,11,13-16,18-20,23,29]$. The other models' results are given in Figure 3 .

The population that was included in this casecontrol study was from the Anatolian region which has a higher incidence rate compared to the other ${ }^{[30]}$ and also compared to Ates et al's report ${ }^{[5]}$. Although both groups are Turkish, our group of patients came from a more homogenous population in origin, which may explain the inconsistency of the results of ours and theirs.

\section{CONCLUSION}

Many different factors play roles in developing active diseases which includes complex molecular interactions in the immune system. In those, both acquired and inherited factors show their effects. The inconsistency of the results of single SNPs maybe explained by these factors, not only one or two SNPs can be used as a biomarker for developing active TB but maybe haplotypes should be considered. It is also possible to think the variations of many genes that take part in the host immune response contribute to develop an active form in the individuals. When the effect of vitamin D is thought, we considered that VDR was an important factor for developing a proper immune response for infectious diseases, so we focused on its polymorphisms, and even though the meta-analysis found no association between the SNPs we investigated and the PTB, we found an association in our group of patients for Fok I polymorphism in our case-control study and Taq polymorphism results showed parallelism with the meta-analysis.

The reason why some people develop active $\mathrm{TB}$ but others not is still in question and in order to be protected from $M$. tuberculosis, the puzzle needs to be solved by investigating other genes' polymorphisms with larger number of subjects.

\section{ETHICS COMMITTEE APPROVAL}

This study was obtained from İnönü University Faculty of Medicine Clinical Researches Ethical Committee (Date: 27.07.2016, Decision No: 2016/150).

\section{CONFLICT of INTEREST}

The authors declare no conflict of interests.

\section{AUTHORSHIP CONTRIBUTIONS}

Concept and Design: CA, HGB

Data Collection or Processing: CA, HGB, RDV

Analysis/Interpretation: CA, RDV

Literature Search: CA, HGB

Writing: CA, HGB

Final Approval: CA, HGB, RDV

\section{REFERENCES}

1. World Health Organization (WHO). Global Tuberculosis Report 2019. Geneva. Licence: CC BY-NC-SA 3.0 IGO.

2. Vaizoğlu RD, Acar C. The Relationship Between Tuberculosis and TLR Gene Polymorphisms. Türk Mikrobiyoloji Cem Derg 2019;49(1):1-10

3. Chocano-Bedoya P, Ronnenberg AG. Vitamin D and Tuberculosis. Nutrition Reviews 2009;67(5):289-293.

4. Gözükara Bag HG. Association between COMT gene rs165599 SNP and schizophrenia: A meta-analysis of case-control studies. Mol Genet Genomic Med 2018;6(5):845-4

5. Ates O, Dolek B, Dalyan L, Musellim B, Ongen G, Topal-Sarikaya $A$. The association between Bsml variant of vitamin $D$ receptor gene and susceptibility to tuberculosis. Mol Biol Rep 2011;38(4):2633-6.

6. Bellamy R, Ruwende C, Corrah T, McAdam KPWJ, Thursz M, Whittle HC, et al. Tuberculosis and chronic hepatitis $b$ virus Infection in africans and variation in the vitamin d receptor gene. J Infect Dis 1999;179(3):721-4.

7. Lee SW, Chuang TY, Huang HH, Liu CW, Kao YH, WuLSH. VDR and VDBP genes polymorphisms associated with susceptibility to tuberculosis in a Han Taiwanese population. I Microbiol Immunol and Inf 2016;49(5):783-7.

8. Banoeia MM, Mirsaeidib MS, Houshmanda M, Tabarsic $P$, Ebrahimic G, Zargaric L, et al. Vitamin D receptor homozygote mutant $t$ and $b b$ are associated with susceptibility to pulmonary tuberculosis in the Iranian population. International Journal of Infectious Diseases 2010;14:84-5. 
9. Panwar A, Garg RK, Malhotra HS, Jain A, Singh AK, Prakash $S$, et al. 25-Hydroxy Vitamin D, Vitamin D Receptor and Toll-like Receptor 2 Polymorphisms in Spinal Tuberculosis. Medicine 2016;95(17):3418.

10. Rizvi I, Garg RK, Jain A, Malhotra HS, Singh AK, Prakash $S$, et al. Vitamin D status, vitamin D receptor and toll like receptor-2 polymorphisms in tuberculous meningitis: a case-control study. Infection 2016;44(5):633-40.

11. Wilkinson RJ, Llewelyn M, Toossi Z, Patel P, Pasvol G, Lalvani $A$, et al. Influence of vitamin $D$ deficiency and vitamin $D$ receptor polymorphisms on tuberculosis among Gujarati Asians in West London: a case-control study. Lancet 2000;355(9204):618-21.

12. Delgado JC, Baena A, Thim S, Goldfeld AE. Ethnic-Specific Genetic Associations with Pulmonary Tuberculosis. The Journal of Infectious Diseases 2002;186(10):1463-8.

13. Bornman L, Campbell SJ, Fielding K, Bah B, Sillah J, Gustafson $P$, et al. Vitamin $D$ Receptor Polymorphisms and Susceptibility to Tuberculosis in West Africa: A Case-Control and Family Study. The Journal of Infectious Diseases 2004;190(9):1631-41.

14. Lombard Z, Dalton $D L$, Venter $P A$, Williams $R C$, Bornman $L$. Association of $H L A-D R,-D Q$, and vitamin $D$ receptor alleles and haplotypes with tuberculosis in the venda of South Africa. Human Immunology 2006;67(8):643-654.

15. Olesen $R$, Wejse $C$, Velez DR, Bisseye C, Sodemann M, Aaby $P$, et al. DC-SIGN (CD209), pentraxin 3 and vitamin D receptor gene variants associate with pulmonary tuberculosis risk in West Africans. Genes and Immunity 2007;8:456 467.

16. Kang TJ, Jin SH, Yeum CE, Lee SB, Kim CH, Lee SH, et al. Vitamin D Receptor Gene Taq I, Bsm I and Fok I Polymorphis$m s$ in Korean Patients with Tuberculosis. Immune Network 2011;11(5):253-257.

17. Alexandra SG, Georgiana DC, Nicoleta C, Daniela PM, Traian S, Veronica S. Apa I and Taq I polymorphisms of VDR (vitamin $D$ receptor) gene in association with susceptibility to tuberculosis in the Romanian population. Romanian Biotechnol Lett 2013;18(1):7956-62.

18. Rashedi J, Asgharzadeh M, Moaddab SR, Sahebi L, Khalili $M$, Mazani $M$, et al. Vitamin D receptor gene polymorphism and vitamin D plasma concentration: correlation with susceptibility to tuberculosis. Adv Pharm Bull 2014;4(2):60711.

19. Salimi S, Farajian-Mashhadi F, Alavi-Naini R, Talebian G, Narooie-Nejad M. Association between vitamin $D$ receptor polymorphisms and haplotypes with pulmonary tuberculosis. Biomed Rep 2015;3(2):189-94.

20. Fernández-Mestre $M$, Villasmil $A$, Takiff $H$, Fuentes Alcalá Z. NRAMP1 and VDR Gene Polymorphisms in Susceptibility to Tuberculosis in Venezuelan Population. Disease Markers 2015; Article ID 860628, p:7.
21. Harishankar M, Selvaraj P. Regulatory role of $C d x-2$ and Taq I polymorphism of vitamin D receptor gene on chemokine expression in pulmonary tuberculosis. Hum Immunol 2016;77(6):498-505.

22. Jafari $M$, Nasiri MR, Sanaei $R$, Anoosheh S, Farnia P, Sepanjnia $A$, et al. The NRAMP1, VDR, TNF- $\alpha$, ICAM1, TLR2 and TLR4 gene polymorphisms in Iranian patients with pulmonary tuberculosis: A case-control study. Infect Genet Evol 2016;39:92-98.

23. Devi KR, Mukherjee K, Chelleng PK, Kalita S, Das U, Narain K. Association of VDR gene polymorphisms and $22 \mathrm{bp}$ deletions in the promoter region of TLR2 22 (-196-174) with increased risk of pulmonary tuberculosis: A case-control study in tea garden communities of Assam. I Clin Lab Anal 2018;32(7):22562.

24. Silva-Ramírez B, Saenz-Saenz CA, Bracho-Vela LA, Katia Peñuelas-Urquides K, Mata-Tijerina V, Escobedo-Guajardo $B L$, et al. Association between vitamin $D$ receptor gene polymorphisms and pulmonary tuberculosis in a Mexican population. Indian J Tuberculosis 2019;66(1):70-75.

25. Marashian SM, Farnia P, Seyf S, Anoosheh S, Velayati AE. Evaluating the role of vitamin $D$ receptor polymorphisms on susceptibility to tuberculosis among Iranian patients: a case-control study. Tüberk Toraks 2010;58(2):147-153.

26. Liu W, Cao WC, Zhang CY, Tian L, Wu XM, Habbema JDF, et al. VDR and NRAMP1 gene polymorphisms in susceptibility to pulmonary tuberculosis among the Chinese Han population: a case-control study. Int I Tuberc Lung Dis 2004;8(4):428-34.

27. Wu L, Deng $H$, Zheng $Y$, Mansjo $M$, Zheng $X$, Hua $Y$, et al. An association study of NRAMP1, VDR, MBL and their interaction with the susceptibility to tuberculosis in a Chinese population. International J Infect Dis 2015;38:129-35.

28. Singh A, Gaughan JP, Kashyap VK. SLC11A1 and VDR gene variants and susceptibility to tuberculosis and disease progression in East India. Int I Tuberc Lung Dis 2011;15(11):1468-74.

29. Sinaga BYM, Amin $M$, Siregar $Y$, Sarumpaet SM. Correlation between Vitamin D Receptor Gene Fok I and Bsm I Polymorphisms and the Susceptibility to Pulmonary Tuberculosis in an Indonesian Batak-ethnic Population. Acta Med Indones 2014;46(4):275-82.

30. Acar C, Kurt AG, Vaizoglu RD, Gozukara GH, Arıca Z, Durmaz $B$, et al. Apo E genotyping in tuberculosis patients from Malatya. J Turgut Ozal Med Cent 2015;22(3):180-3.

\section{Address for Correspondence/Yazıșma Adresi}

\section{Dr. Ceren ACAR}

İnönü Üniversitesi Fen Edebiyat Fakültesi, Moleküler Biyoloji ve Genetik Anabilim Dalı, Malatya-Türkiye

E-posta: ceren.acar@inonu.edu.tr 